\title{
Is There any Blood on my Hands? Deportation as a Crime of International Law
}

\author{
VINCENT CHETAIL*
}

\begin{abstract}
The present article revisits international criminal law as a tool for sanctioning the most patent abuses against migrants. Although deportation is traditionally considered as an attribute of the state inherent to its territorial sovereignty, this prerogative may degenerate into an international crime. The prohibition of deportation has been a well-established feature of international criminal law since the Nuremberg trials following the Second World War. This prohibition has been further refined over the past I 5 years by an extensive jurisprudence of the International Criminal Tribunal for the former Yugoslavia, the International Criminal Tribunal for Rwanda and the International Criminal Court.

Against such a background, this article demonstrates that, in some circumstances, deportation may amount to a war crime, a crime against humanity or even a crime of genocide, depending on the factual elements of the case and the specific requirements of the relevant crime. This article accordingly reviews the constitutive elements of each crime and transposes them into the context of migration control. It highlights in turn that, although its potential has been neglected by scholars and practitioners, international criminal law has an important role to play for domesticating the state's prerogative of deportation and infusing the rule of law into the field of migration. The article concludes that there are reasonable grounds for asserting that a crime against humanity would have been committed in the Dominican Republic and Australia with regard to their deportation policy.
\end{abstract}

\section{Key words}

crime against humanity; deportation; genocide; migration

\section{INTRODUCTION}

Is there any blood on my hands? This is a question shared by an increasing number of people who observe or carry out migration control in the Global North and the rest of the world. ${ }^{\mathrm{I}}$ This questioning has become a particularly controversial issue in Australia where the policy of returning asylum-seekers and the accompanying mistreatment are alleged to amount to crimes against humanity. ${ }^{2}$ The situation

Professor of International Law, Graduate Institute of International and Development Studies (Geneva) [vincent.chetail@graduateinstitute.ch]

I See L. Smith, 'Ex-Immigration Official - Is There the Blood of Asylum Seekers on my Hands?', 3I January 20I4, available at www.crikey.com.au/20I4/oI/30/ex-immigration-officer-is-thereasylum-seeker-blood-on-my-hands/, from which the title of this article is inspired.

2 On 22 October 20I4, independent federal MP A. Wilkie requested the Office of the Prosecutor of the International Criminal Court to initiate a proprio motu investigation into crimes against 
in Australia is, however, far from unique. Abuses against migrants are regularly reported in various countries of the world, such as in Greece ${ }^{3}$ and Qatar ${ }^{4}$ to quote a few.

This raises the question whether international criminal law has a role to play in sanctioning the most patent violations of migrants' rights. Such an appraisal calls for two preliminary caveats. On the one hand, while the narrative of abuses has become common place for describing the situation of migrants across the world, it captures only one aspect of international migration. In this field, as in many others, abuses are more visible than compliance. Furthermore, in the context of migration control, deportation primarily concerns undocumented migrants, who still represent a limited portion of the total population of migrants (approximately Io per cent). ${ }^{5}$

On the other hand, international criminal law has been conceived in the particular context of armed conflicts and other related situations of generalized violence. The threshold for triggering international criminal responsibility is accordingly high and its transposition into the specific context of migration control is not obvious. Although international crimes should be strictly construed, it remains that the prohibition of deportation has been a well-established feature of international criminal law since I $945 .{ }^{6}$ This prohibition has been further endorsed by the Statute of the International Criminal Court (Rome Statute), which codifies to a great extent, customary international law. ${ }^{7}$ Moreover, over the past I5 years, the International Criminal Tribunals for the former Yugoslavia (ICTY) and for Rwanda (ICTR), as well as the International Criminal Court (ICC) have developed extensive jurisprudence on forcible displacement. Against such a background, this article demonstrates that

humanity against the Australian Prime Minister and I9 members of his cabinet including the Minister for Immigration and Border Protection; S. Medhora, 'Asylum-seekers: Andrew Wilkie takes Australia to International Criminal Court', The Guardian, 22 October 2014, available at www.theguardian.com/australia-news/20 I4/oct/22/asylum-seekers-andrew-wilkie-takes-australia-tointernational-criminal-court.

3 Human Rights Watch, 'Unwelcome Guests. Greek Police Abuses of Migrant in Athens', I 2 June 20I3; Report of the Special Rapporteur on the Human Rights of Migrants, Mission to Greece, UN Doc. A/HRC/23/46/Add.4 (2013); Committee against Torture (CAT), Concluding Observations: Greece, UN Doc. CAT/C/GRC/CO/5-6 (2012), paras. I2, I7-25; Amnesty International, 'Greece. The End of the Road for Refugees, Asylum-Seekers and Migrants, (2012).

4 Report of the Special Rapporteur on the Human Rights of Migrants, Mission to Qatar, UN Doc. A/HRC/26/35/Add.I (20I4); CAT, Concluding Observations: Qatar, UN Doc. CAT/C/QAT/CO/2 (2OI3), paras. IO, I3, I8, 20-I; Amnesty International, “My Sleep is my Break”. Exploitation of Migrant Domestic Workers in Qatar', (20I4); Human Rights Watch, 'Building a Better World Cup. Protecting Migrant Workers in Qatar Ahead of FIFA 2022', (2012).

5 International Organization for Migration (IOM), World Migration Report 2010, (2010) at 29. The definition provided by the International Law Commission Draft Articles on the Expulsion of Aliens is broader and not limited to forced removal of undocumented migrants. Its Art. 2(a) defines expulsion as 'a formal act, or conduct consisting of action or omission, attributable to a state, by which an alien is compelled to leave the territory of that state.' ILC Draft Articles on the Expulsion of Aliens, 2014 YILC, Vol. 2 (Part Two).

6 I945 Agreement for the Prosecution and Punishment of Major War Criminals of the European Axis and Charter of the International Military Tribunal, 82 UNTS 280, Art. 6(c); Control Council Law No. Io, Punishment of Persons Guilty of War Crimes, Crimes Against Peace and Against Humanity, 20 December I 945,3 Official Gazette Control Council for Germany, 50-5 (I946), Art. I I(I)(c); I946 Charter of the International Military Tribunal for the Far East, annexed to the Special Proclamation of the Supreme Commander of the Allied Powers Establishing an International Military Tribunal for the Far East, Tokyo, I9 January I946, (as amended by General Order No. 20, 26 April I946, Art. V(c).

$7 \quad$ I998 Rome Statute of the International Criminal Court, 2 I 87 UNTS 3. 
deportation can amount to a war crime (Section I), a crime against humanity (Section 2), or a crime of genocide (Section 3), depending on the circumstances of the case and the specific requirements of the relevant crime.

\section{Deportation AS A WAR CRIME}

According to Article 477 of the Fourth Geneva Convention Relative to the Protection of Civilian Persons in Time of War (GC IV), 'unlawful deportation or transfer ... of a protected person' constitutes a grave breach of the Convention. ${ }^{8}$ State parties are thus not only bound to criminalize it in their domestic legislation, but they also have to investigate and prosecute any perpetrators of such a war crime. This criminal offence has been reaffirmed by Protocol I Additional to the Geneva Conventions (API) ${ }^{9}$ and the Rome Statute. ${ }^{\text {IO }}$

Although grave breaches are confined to international armed conflicts (IACs), the Rome Statute acknowledges that unlawful deportation or transfer can also constitute a war crime in non-international armed conflicts (NIACs). ${ }^{\text {II }}$ Hence deportation can amount to a war crime in IACs, military occupations, and NIACs, though the very content of the relevant criminal offence substantially varies from one situation to another.

\section{I. Deportation as a war crime in international armed conflicts and occupa- tion}

In times of IAC, Article 8 of the Rome Statute refers twice to the prohibition of deportation and transfer: Article 8(2)(a)(vii) acknowledges 'unlawful deportation and transfer' as a grave breach of GC IV; Article 8(2)(b)(viii) then reproduces Article $85(4)$ (a) of API by referring to 'the deportation or transfer of all or parts of the population of the occupied territory within or outside this territory'. Both crimes are subordinated to three substantial requirements governing their territorial, personal and material scope.

Regarding the scope of rationae loci, unlawful deportation must take place in an IAC or a military occupation. Although the notion of armed conflict has raised longstanding controversies, one can fairly state that an IAC is presumed in three situations. First, as restated in the famous Tadić case, 'an armed conflict exists whenever there is a resort to armed force between states'. ${ }^{\text {I2 }}$ Second, according to the Tadic Appeal Judgment, IACs cover internal conflicts that have been internationalized. ${ }^{\mathrm{I}}$ Third, API includes wars of national liberation within the notion of IAC (Art. I(4)).

Although falling within the definition of IAC, the notion of occupation is indifferent to the level of violence, due to the fact that no armed resistance is required

\footnotetext{
I949 Geneva Convention Relative to the Protection of Civilian Persons in Time of War (GC IV), 75 UNTS 287. I977 Protocol Additional to the Geneva Conventions of I2 August 1949, and Relating to the Protection of Victims of International Armed Conflicts (Protocol I), I 977, I I 25 UNTS 3, Art. 85(4)(a).

Ibid., at Arts. 8(2)(a)(vii), 8(2)(b)(viii).

Ibid., at Art. 8(2)(e)(viii).

Prosecutor v. Tadić, Decision on the Defence Motion for Interlocutory Appeal on Jurisdiction, Case No. IT-94-I-T, A.Ch, 2 October I995, para. 70.

I 3 Prosecutor v. Tadić, Judgement, Case No. T-94-I-A, I5 July I999, para. 84.
} 
under Common Article 2 of the four Geneva Conventions. Article 42 of the Hague Regulations defines occupation as including any territory which 'is actually placed under the authority of the hostile army', that is, 'where such authority has been established and can be exercised'. ${ }^{4}$ The ultimate criterion of an occupation thus relies on the effective control of a foreign territory. Needless to say, the requirement of an IAC or a military occupation represents a relatively high threshold. Such a nexus accordingly limits the relevance of the war crime of deportation in the broader context of migration control. The War Report 2013 identified only two IACs (between Israel and Syria, and between India and Pakistan) and nine cases of belligerent occupation in Azerbaijan, Cyprus, Eritrea, Georgia, Lebanon, Moldova, Palestine, Syria, and Western Sahara. ${ }^{\text {I5 }}$

The second requirement relates to the personal scope of war crimes, for victims of unlawful deportation must be considered as 'protected persons' under international humanitarian law (IHL). This condition is more easily fulfilled than the previous one. Indeed, Article 4 of GC IV defines them in broad terms as 'those who, at a given moment and in any manner whatsoever, find themselves ... in the hands of a Party to the conflict or Occupying Power of which they are not nationals'. While this definition clearly covers enemy nationals, it also includes any other nationals from a third state who are in the hands of a party to the conflict or occupying power. ${ }^{16}$ As a result, migrants in the territory of the above mentioned states - such as Lebanon, Morocco or Eritrea - can be considered as protected persons under IHL.

The last set of requirements concerns the very notion of 'unlawful deportation and transfer'. In IACs, it primarily refers to a violation of Article 45 of GC IV. According to this last provision, transfer is prohibited in three specific circumstances: the destination state is not party to the Geneva Convention (Art. 45(I)); it is unwilling or unable to apply it (Art. 45(3)); or it persecutes protected persons for their political opinion or religious belief (Art. 45(4)).

The notion of transfer is however ambiguous and its difference from the related notion of deportation is far from obvious. ${ }^{17}$ The ICRC Commentary proposes a generic and factual definition of transfer encompassing '[a]ny movement of protected persons to another State, carried out by the Detaining Power on an individual or collective basis', ${ }^{18}$ such as 'repatriation, the returning of protected persons to their country of residence or their extradition'. ${ }^{\text {I9 }}$ Although this inclusive definition of

I 4 I907 Hague Convention (IV) Respecting the Laws and Customs of War on Land and its Annex: Regulation Concerning the Laws and Customs of War on Land, I8 October I907, I87 CTS 227.

I5 S. Casey-Maslen (ed.), The War Report 20I3 (2014), 9. Ukraine should be added to this list.

I6 Yet nationals of a neutral state which has normal diplomatic representation in the belligerent state are not considered as protected persons under Art. 4, like nationals of a co-belligerent state in the belligerent or occupying state.

I7 For further discussions on the alleged differences between transfer, deportation and other related measures of forcible displacement in IHL, see V. Chetail, 'The Transfer and Deportation of Civilians', in A. Clapham, P Gaeta, and M. Sassòli (eds.), The I 949 Geneva Conventions: A Commentary (2015), I I85-I 2I3; M. Jacques, Armed Conflict and Displacement. The Protection of Refugees and Displaced Persons under International Humanitarian Law (20I 2), I 28-34; J. Henckaerts, 'Deportation and Transfer of Civilians in Time of War', (I993) 26 VJTL 469, at 5 I9.

I8 J. Pictet, The Geneva Conventions of I 2 August I949: Commentary, Geneva Convention (IV) Relative to the Protection of Civilian Persons in Time of War (1960), 266.

Ibid. 
transfer can be easily transposed into the forced removal of migrants, the ICRC Commentary curiously excludes deportation from the scope of Article 45:

In the absence of any clause stating that deportation is to be regarded as a form of transfer, this Article would not appear to raise any obstacle to the right of Parties to the conflict to deport aliens in individual cases when State security demands such action. ${ }^{20}$

This interpretation remains nonetheless dubious for three main reasons. Excluding expulsion from the notion of transfer leads to an absurd result in contradiction with the very object and purpose of this provision: a state can simply evade its obligation by deporting protected persons towards states in which transfer is precisely prohibited by Article 45. Furthermore, the Rome Statute refers to both 'unlawful deportation and transfer', which thus presumes that the two are prohibited as grave breaches. This interpretation finds additional support by analogy to human rights law and refugee law, since under these two branches of international law, the principle of non-refoulement includes any type of forced removals (whether labelled expulsion or transfer). ${ }^{2 I}$

In times of occupation, the prohibition of deportation and transfer is more straightforward. Alongside Article 49 of GC IV and Article 85(4)(a) of API, the Rome Statute refers to 'the deportation or transfer of all or parts of the population of the occupied territory within or outside this territory'. Any kind of transfer or deportation is thus prohibited in categorical terms. In contrast to the relevant war crime in time of IAC, the destination of the forcible removal is immaterial. As restated by Article 49(I) of GC IV, the motive is equally irrelevant. The general nature of the prohibition triggers another substantial feature: it applies without regard to the fact that protected persons have committed crimes or any other activities that may be a threat to public order or national security. Nonetheless, while unlawful deportation and transfer of one single protected person can be a war crime in IACs, during occupation, the term 'all or parts of the population' requires the forced displacement of more than one civilian.

\subsection{Deportation as a war crime in non-international armed conflict}

Deportation can also amount to a war crime in NIACs. While Common Article 3 of the four Geneva Conventions does not define NIACs, the ICTY has come up with two cumulative conditions to assert its existence: (i) the conflict needs to be protracted, that is, armed violence has to be of a certain intensity; and (ii) the armed group(s) need(s) to display a minimum of organization. ${ }^{22}$ Given that most contemporary armed conflicts are of an internal character, this war crime of deportation can be applied to a broader set of situations. According to the War Report 2013, NIACs were taking place in 17 states: Afghanistan, Central African Republic, Colombia,

Ibid.

For further discussions, cf. Section 3.I., infra.

Tadić, supra note I2, at para. 70; Prosecutor v. Limaj, Bala, and Musliu, Judgement, Case No. IT-03-66-T, T.Ch. II, 30 November 2005, para. 84; Prosecutor v. Haradinaj, Blaj, and Brahimaj, Judgement, Case No. IT-04-84-T, T.Ch.

I, 3 April 2008, paras. 49, 60. 
the Democratic Republic of Congo, India, Mali, Mexico, Myanmar, Nigeria, The Philippines, Somalia, South Sudan, Sudan, Syria, Thailand, Turkey, and Yemen. ${ }^{23}$

Article 8(2)(e)(viii) of the Rome Statute defines the war crime of deportation in NIACs as 'ordering the displacement of the civilian population for reasons related to the conflict, unless the security of the civilians involved or imperative military reasons so demand'. This criminal offence is subject to three substantial qualifications.

First, the war crime under Article 8(2)(e)(viii) of the Rome Statute only concerns an order to displace, and not forcible displacement as such. ${ }^{24}$ This is the only crime within the entire Rome Statute which specifically requires such an order. Thus, while excluding executors, this war crime is limited to the persons who have de jure or de facto authority to give such an order, be it a military or a civilian (including politicians and representatives of states or non-state armed groups). ${ }^{25}$ In any event, one can expect this requirement to be easily established in the case of deportation, for such a forced removal presupposes by definition a decision from the relevant authority.

Second, to be considered as a war crime in NIAC, the deportation order must be adopted 'for reasons related to the conflict'. This qualification is the most substantial one and considerably mitigates the reach of this war crime. Both the ICRC Commentary and the case-law do not provide a definition of these reasons which are thus assessed by reference to the particular circumstances of each case. It is nonetheless obvious that these reasons are broader than purely military ones. They include other reasons typical in an armed conflict whether political, economic, territorial, national, religious or ethnic. On the other hand, deportation of migrants based on their undocumented status without further reasons related to the conflict is not covered by Article 8(2)(e)(viii) of the Rome Statute.

Third, even if there is a reason related to the conflict, the Rome Statute provides two exceptions when deportation is ordered for the security of the civilians or imperative military reasons. Though the relevant authority retains a substantial margin of appreciation, these two exceptions are exhaustive and must be interpreted in good faith with due regard to the principle of prohibition contained in Article $8(2)$ (e)(viii). The first of these is aimed at protecting civilians from the hostilities and any other threat to their integrity. ${ }^{26}$ The second one is more problematic as it

23 The War Report 2013, supra note I5, at Io. Among them, eight states have ratified the Rome Statute: Afghanistan, Central African Republic, Colombia, Democratic Republic of Congo, Mali, Mexico, Nigeria, and The Philippines.

24 R. Piotrowicz, 'Displacement and Displaced Persons', in E. Wilmshurst and S. Breauat (eds.), Perspectives on the ICRC Study on Customary International Humanitarian Law (2007), at 347; see J. Willms, 'Without Order, Anything Goes? The Prohibition of Forced Displacement in Non-International Armed Conflict', (2009) 9I (875) International Review of the Red Cross, 547-65.

25 Willms, supra note 24, at 562; K. Dörmann, 'Preparatory Commission for the International Criminal Court: The Elements of War Crimes: Part II: Other Serious Violations of the Laws and Customs Applicable in International and Non-International Armed Conflicts', (2001) 83(842) International Review of the Red Cross, 46I-88. However, once it is established that an order has been given, it may be possible to hold other persons responsible for this crime by using modes of liability such as common purpose liability or aiding and abetting liability.

26 This is obviously the case for removing civilians from areas with military objectives as restated by Art. I3(I) of AP II. 
justifies deportation for 'imperative military reasons' on its own without any specific consideration for the displaced persons.

Nevertheless, not all military objectives can justify deportation. As observed by the ICRC, " $[t]$ he situation should be scrutinized most carefully as the adjective "imperative" reduces to a minimum cases in which displacement may be ordered'. ${ }^{27}$ The plurality of the 'military reasons' at stake arguably reinforces this understanding. Therefore, only severe and imperative military reasons can justify deportation. As a result of the two limitative exceptions in Article 8(2)(e)(viii), deportation remains unlawful when ordered on any other ground, such as political or economic reasons, public order, national security or the undocumented status of deportees.

In sum, while Article 8(2)(e)(viii) is virtually applicable to more states than its equivalent in IAC, the various requirements of the Rome Statute considerably restrict the scope of this war crime. Therefore, it is bound to be applied in a fairly limited set of circumstances. The same observation can be made with regard to the war crime of deportation in IACs. The existence of such conflicts remains relatively rare and the prohibition of unlawful deportation is further circumscribed by the wording of Article 45. This last provision still allows transfer and deportation to a party to GC IV when it is willing and able to apply it and there is no risk of political or religious persecution.

By contrast, the war crime of deportation in time of occupation is potentially applicable to a broader number of states (including those with a substantial number of undocumented migrants, such as Morocco). Furthermore, once the nexus with an occupied territory is established, the prohibition of deportation is broad and inclusive compared to IACs and NIACs: it bans any deportations irrespective of their destination, purpose or the crimes allegedly committed by the deportees.

\section{Deportation AS A CRIME AgAinst humanity}

Parallel to the relevant war crime in both international and non-international armed conflicts, deportation can amount to a crime against humanity provided that it is part of a widespread or systematic attack against civilians. In contrast to war crimes, the latter does not require a nexus with an armed conflict and can be thus committed in time of peace. ${ }^{28}$ Because of its potentially broader scope, crimes against humanity clearly constitute the most relevant avenue for criminalizing deportation.

Nonetheless, not all acts of deportation qualify as a crime against humanity. Two sets of conditions are required: (i) the underlying offence must correspond to the definition of deportation provided by the Rome Statute; (ii) it must have been committed in the context of a widespread or systematic attack directed against civilian population.

27 Y. Sandoz, C. Swinarski, and B. Zimmermann (eds.), Commentary on the Additional Protocols of 8 June 1977 to the Geneva Conventions of I 2 August I949 (I987), at I473.

28 Tadić, supra note I2, at para. I4I. 


\section{I. The definition of deportation}

Deportation has been acknowledged as a crime against humanity in a broad range of instruments, including the ICTY Statute (Art. 5(d)); the ICTR Statute (Art. 3(d)); the Statute of the Special Court of Sierra Leone (Art. 2(d)); UNTAET Regulation 2000/I5 on the establishment of the Cambodian Extraordinary Courts (section 5.I(d)); and the Rome Statute (Art. 7(I)(d)). The Rome Statute is the first one which provides a definition of deportation. According to its Article 7(2)(d), “Deportation or forcible transfer of population" means forced displacement of the persons concerned by expulsion or other coercive acts from the area in which they are lawfully present, without grounds permitted under international law.'

This definition is accordingly based on three cumulative conditions: (i) the forcible character of the displacement; (ii) the lawful presence of the deportee; (iii) the absence of a permitted ground under international law. If one of these conditions is lacking, deportation can still fall within the residual category of 'other inhumane acts' under Article 7(I)(k) of the Rome Statute when the removal process is carried out in such a way that it causes 'great suffering, or serious injury to body or to mental or physical health'. ${ }^{29}$

\section{I.I. Forcible character of the displacement}

This first requirement is easily established in case of expulsion across an international border which is by nature a coercive measure of removal. Both the ICTY case-law and the Elements of Crimes further provide a broad definition of the forcible character of displacement, including both physical and psychological force 'such as that caused by fear of violence, duress, detention, psychological oppression or abuse of power'. ${ }^{30}$ As a result, the forcible character of displacement is not only inherent to the very act of deporting someone outside the territory of a state. It can also be inferred from the surrounding circumstances when non-citizens are bound to leave the territory in order to escape from mistreatment, arbitrary detention or abuse of power as it may happen in immigration detention centres.

By contrast, voluntary return or departure does not amount to an act of deportation. As restated by the ICTY, 'the displacement of persons is only illegal where it is forced, i.e. not voluntary'. ${ }^{3}$ However, even in case of voluntary departure, the real consent of the concerned persons is of paramount importance. ${ }^{32}$ Significantly the fact that the person has expressed his consent does not obviate the need for inquiring into the genuine voluntary nature of such a consent. ${ }^{33}$ Thus 'an apparent consent

29 See Prosecutor v. Kupreškić, Judgement, Case No. IT-95-I6, T.Ch. I., I 4 January 200o, para. 566.

30 Report of the Preparatory Commission for the ICC, Finalized Draft Text of the Elements of the Crimes, PCNICC/2000/INF/3/Add.2, I I (2000); see also Prosecutor v. Krstić, Judgement, Case No. IT-98-33-T, 2 August 200I, para. 529; Prosecutor v. Krnojelac, Judgement, Case No. IT-97-25-T, T.Ch. II, I5 March 2002, para. 475; Prosecutor v. Stakić, Judgement, Case No. IT-97-24-A, A. Ch., 22 March 2006, para. 28I.

3I Prosecutor v. Simić, Tadić, and Zarić, Judgement, Case No. IT-95-9-T, T.Ch. II, I7 October 2003, para. I 25.

32 Prosecutor v. Krnojelac, Judgement, Case No. IT-97-25-A, A. Ch., I 7 September 2003, para. 229.

33 Stakić, supra note 30, para. 279; see also Prosecutor v. Blagojević and Jokić, Judgement, Case No. IT-02-6o-T, T.Ch. I. Section A, I 7 January 2005, para. 596; Prosecutor v. Kunarac, Kovac, and Vukovic, Judgement, Case No. IT-96-23-7 \& IT-96-23/I-T, 22 February 200I, para. 460. This was cited with approval in Prosecutor v. Kunarac, Kovac, and Vukovic, Judgement, Case No. IT-96-23 \& IT-96-23/I-A, I 2 June 2002, paras.I27-8. 
induced by force or threat of force should not be considered to be real consent'. ${ }^{34}$ Likewise, the ICTY further specified that 'the assistance by humanitarian agencies, such as UNPROFOR, ICRC, and NGOs, in facilitating displacements, does not of itself render an otherwise unlawful transfer lawful'. ${ }^{35}$ This line of reasoning is presumably applicable in the context of the so-called assisted voluntary returns carried out with the assistance of the International Organisation for Migration (IOM). Accordingly, such programmes do not prejudice the consent of returnees, which must be free and real according to the prevailing circumstances of the time. Otherwise voluntary repatriation may become unlawful deportation.

\section{I.2. Lawful presence}

The second constitutive element of deportation as a crime against humanity is more demanding than the first one as it requires the lawful presence of the deportees. According to Bassiouni, "the inclusion of "lawfully present" permits a state to deport one who is not afforded the right to remain in that state under its domestic laws'. ${ }^{36}$ This assertion however calls for two important qualifications. On the one hand, the notion of presence does not equate with that of residence; no particular duration is thus required as confirmed by the ICTY. ${ }^{37}$ Likewise, there is no need to prove the intent to permanently displace the victims..$^{8}$

On the other hand, deportations carried out in conformity with domestic law can still be unlawful under international law. Hence the lawfulness of the presence cannot be determined on the sole ground of domestic law. Though this issue has not yet been settled by the jurisprudence, most - if not all - commentators consider that lawful presence under Article 7(2)(d) of the Rome Statute must be assessed not only on the basis of domestic law but also by reference to international law. ${ }^{39}$ Indeed, 'any other reading would make the definition of deportation meaningless as it would permit a government to declare that the people to be deported were not "lawfully present" in the territory of a State ... and escape international criminal responsibility'.40

Against such a frame, a non-citizen is 'lawfully present' under Article 7(2)(d) of the Rome Statute when he/she has a valid entry or residence document under domestic law. However, even those who are undocumented under domestic law can still be lawfully present under international law. This can happen in a variety of situations when, for instance, their undocumented status results from arbitrary deprivation of

International Criminal Law (200I), Iog; Y. Jurovics, 'Article 7 - Crimes contre l'humanité', in J. Fernandez and X. Pacreau (eds.), Statut de Rome de la Cour pénale internationale. Commentaire Article Par Article (2012), 430; K. Ambos and S. Wirth, 'The Current Law of Crimes against Humanity. An analysis of UNTAET Regulation I5/2000', (2002) I3 Criminal Law Forum, 60.

40 C.K. Hall, 'Crimes against Humanity, para. I (d)', in O. Triffterer (ed.), Commentary on the Rome Statute of the International Criminal Court (I999), 248. 
nationality, illegal destruction or confiscation of entry/residence document, arbitrary refusal of family reunification or any other related measures in contradiction with international law. ${ }^{4 \mathrm{I}}$

In some other instances, a lawful presence is even granted by international law such as in the great number of bilateral treaties of establishment and regional free movement agreements. Furthermore, asylum-seekers and refugees benefit from the principle of non-refoulement irrespective of their irregular entry or stay. Thus, undocumented asylum-seekers are still lawfully present in the territory as long as their claim to refugee status is pending. Such a lawful presence is reinforced by Article 3 I (I) of the Refugee Convention, which prohibits penalties on account of their illegal entry or stay. This provision is precisely aimed at exempting asylum-seekers from the entry requirements generally imposed on immigrants. It accordingly presumes that asylum-seekers are lawfully present under international law.

\section{I.3. Absence of a permitted ground under international law}

To be considered as a crime against humanity, deportations have to be carried out 'without grounds permitted under international law'. The general reference to international law is obviously not limited to IHL. It also encompasses human rights law and refugee law, which are still applicable in armed conflict or occupation. ${ }^{42}$ Moreover these two branches of international law provide an authoritative frame of reference when a crime against humanity has been committed in time of peace. This is further required by the very object and purpose of the crime against humanity which is conventionally viewed as 'an implementation of human rights norms within international criminal law'. ${ }^{43}$

Against such a frame, though deportation of non-citizens is permitted under some conditions by human rights law and refugee law, it is still prohibited in three main sets of circumstances concerning respectively the type of unlawful deportation, the procedural guarantees governing the expulsion process and the consequence of such forcible removal. First, collective expulsion of aliens is prohibited in absolute terms by a substantial number of instruments, including Article 22(I) of the International Convention on the Protection of the Rights of All Migrant Workers and Members of Their Families (ICRMW); Article 22(9) of the American Convention on Human Rights (ACHR); Article I2(5) of the African Charter on Human and Peoples' Rights (ACHPR); Article 4 of Protocol No. 4 to the European Convention on Human Rights (ECHR) and Article 26(2) of the Arab Charter on Human Rights. ${ }^{44}$

4I See the examples and sources mentioned in the subsequent section.

42 For further discussions and bibliographical references see V. Chetail, 'Armed Conflict and Forced Migration: A Systemic Approach to International Humanitarian Law, Refugee Law and Human Rights Law', in A. Clapham and P. Gaeta (eds.), The Oxford Handbook of International Law in Armed Conflict (2014), 700-34. W. Schabas, The International Criminal Court: A Commentary on the Rome Statute (2010), I 39.

44 See also I998 Commonwealth of Independent States (CIS) Convention on Human Rights and Fundamental Freedoms, 3 I.H.H.R I, 2 I 2, Art. 25(4); 2012 Charter of Fundamental Rights of the European Union, 20I 2/C 326/02, 26 October 201 2, Art. I9(I); among soft-law restatements, see notably CERD, General Recommendation 30: Discrimination against Non-Citizens (2002), UN Doc. CERD/C/64/Misc.I I/rev.3 (2004), para. 26; International Law Association, 'Declaration of Principles of International Law on Mass Expulsion', Report of the $62^{\text {nd }}$ Conference: Seoul (I 986); Council of Europe, Committee of Ministers, 'Twenty Guidelines on Forced Return' (2005), Guideline 3. 
Furthermore, though not explicitly mentioned in the International Covenant on Civil and Political Rights (ICCPR), the Human Rights Committee (HRC) considers that such prohibition is implicit in Article I3, because 'it entitles each alien to a decision in his own case and, hence, article I3 would not be satisfied with laws or decisions providing for collective or mass expulsions'. ${ }^{45}$ The prohibition of collective expulsion is all the more significant since it is arguably grounded in customary international law. States' participation to the relevant treaties is indeed broad and representative: I43 states had ratified at least one of the conventions explicitly prohibiting collective expulsion. More decisively, even states that have not ratified one of these treaties - such as China and Iran - have endorsed the prohibition of collective expulsion. ${ }^{46}$

Second, even when deportation is carried out on an individual basis, it can become unlawful if it violates the procedural guarantees required by international law. Due process guarantees governing deportation have been restated in various regional and universal instruments, ${ }^{47}$ including most notably Article I3 of the ICCPR. This provision endorses the right for the individual to 'submit the reasons against his expulsion and to have his case reviewed by, and be represented for the purpose before, the competent authority', which may only be departed from when 'compelling reasons of national security' so require. As it is apparent from its wording, the threshold of this exception remains relatively high: not just any considerations of national security can justify it. The plural of 'reasons' and the additional qualification based on their 'compelling' nature mean that procedural guarantees can only be departed from in truly exceptional circumstances when there is no other means for protecting the institutions or the population of a state (as it may happen in cases of terrorism or military operations).

By contrast, this exception does not apply when expulsion is decided on any other grounds, such as public order. Furthermore, even when grounded on national security, Article I 3 still requires the deportation order to be 'reached in accordance with the law'. As confirmed by the HRC, the purpose of this requirement is 'clearly to prevent arbitrary expulsions'. ${ }^{48}$

Thirdly and finally, deportation of non-citizens may be unlawful under international law where the result of such forcible removal infringes their basic rights. In particular, deportation can be considered as an arbitrary or unlawful interference with the right to family life under Article I 7 of the ICCPR and other related human

45 Human Rights Committee (HRC), General Comment No. I 5: The Position of Aliens Under the Covenant, UN Doc. HRI/GEN/ı/Rev.9 (Vol. I), (I986), para. Io.

46 Report of the International Law Commission on the Work of its Fifty-Seventh Session, UN Doc. A/C.6/6o/SR.I I (2005), paras. 54 (China) and 84 (Iran).

47 I95 I Convention Relating to the Status of Refugees, I89 UNTS I 50, Art. 32; I 954 Convention Relating to the Status of Stateless Persons, 360 UNTS I 17, Art. 31; I 990 International Convention on the Protection of the Rights of All Migrant Workers and Members of their Families, 2220 UNTS 3, Art. 22; I 984 Protocol No. 7 to the Convention for the Protection of Human Rights and Fundamental Freedoms, as amended by Protocol No. I I, ETS No. I 55, Art. I; African Charter on Human and Peoples' Rights, CAB/LEG/67/3 rev. 5, 2 I ILM 58 (I 982 ), Art. I2(5); I969 American Convention on Human Rights (ACHR), I I44 UNTS I23, Art. 22(6); 2004 Arab Charter on Human Rights (ArCHR), reprinted in I 2 Int'l Hum. Rts. Rep. 893 (2005), Art. 26(2); CIS Convention, supra note 44, Art. 25(3).

48 HRC, General Comment No. I5, supra note 45, para. Io. 
rights treaties. ${ }^{49}$ As restated by the HRC, the arbitrary or unlawful nature of such interference requires a balancing test to weigh the severity of the interference on the individual vis-à-vis the public interest. ${ }^{50}$ While states retain a broad margin of appreciation, this proportionality test is however rarely met in non-criminal cases involving children and/or long-term residents. ${ }^{5 \mathrm{I}}$

Moreover, the principle of non-refoulement prohibits deportation toward a state where there is a real risk of persecution or serious violations of human rights. The ICC has even acknowledged 'the customary rule of non-refoulement' in the recent case of Prosecutor v. Katanga and Ngudjolo Chui. ${ }^{52}$ Indeed, one cannot fail to observe that this 'principle of civilization' 53 is endorsed in an impressive range of universal and regional instruments. ${ }^{54}$ Even in the absence of a specific provision, an implicit prohibition of refoulement has been inferred by treaty bodies from the ICCPR, 55 the Convention on the Rights of the Child, ${ }^{6}$ and the ECHR. ${ }^{57}$ Under human rights law, the principle of non-refoulement remains absolute and cannot be derogated from when there is a real risk of torture, inhuman or degrading treatment. It accordingly applies to asylum-seekers and refugees who are not protected by the Refugee Convention

49 I990 Convention on the Rights of the Child, I577 UNTS 3, Art. I6; ACHR, supra note 47, Art. II(2); I 950 European Convention for the Protection of Human Rights and Fundamental Freedoms, ETS 5, Art. 8; ArCHR, supra note 47, Art. 2 I; I990 African Charter on the Rights and Welfare of the Child, CAB/LEG/24.9/49 (I990) Art. Io; CIS Convention, supra note 44, Art. 9.

50 HRC, Dauphin v. Canada, UN Doc. CPPR/C/96/D/I792/2008, 28 July 2009, paras. 8.3-8.4; HRC, Madafferi $v$. Australia, UN Doc. CCPR/C/8I/D/ıor I/200I, 30 July 2004, paras. 9.7-9.8; HRC, Winata v. Australia, UN Doc. CCPR/C/72/D/930/2000, 26 July 200I, paras. 7.2-7.3; see also Moustaquim v. Belgium, Decision of I 8 February I99I, [I99I] ECHR 3; Sen v. The Netherlands, Decision of 2I December 200I, [200I] App. No. 31465/95, paras. 33-4I; Amnesty International v. Zambia, Com. No. I2/98, [1999] ACHPR Com. No. I2/98, para. 58; IACtHR, Case of Haitian and Haitian-Origin Dominican Persons in the Dominican Republic, Order of the Court, (200I), paras. 85-97.

5 I See Winata v. Australia, supra note 50; Sen v. The Netherlands, supra note 50.

52 Prosecutor v. Katanga and Chui, Decision on an Amicus Curiae Application and on the Requete tendant à obtenir présentations des témoins DRC-D02-P-0350, DRC-D02-P-0236, DRC-D02-P-0228 aux autorités néerlandaises aux fins d'asile, Case No. ICC-oI/04-0I/07-3003, T Ch. II, 9 June 20I I, para. 64. Although the ICC did not discuss the content of such principle under general international law, it primarily referred to 'persons who are at risk of persecution or torture'. Arguably this also includes any other inhuman or degrading treatment. For further discussions on non-refoulement in customary international law. See V. Chetail, 'The Transnational Movement of Persons under General International Law - Mapping the Customary Law Foundations of International Migration Law', in V. Chetail and C. Bauloz (eds.), Research Handbook on International Law and Migration(2014), 35-4I; E. Lauterpacht and D. Bethlehem, 'The Scope and Content of the Principle of Non-Refoulement: Opinion,' in E. Feller, V. Türk, and F. Nicholson (eds.), Refugee Protection in International Law, UNHCR's Global Consultations on International Protection (2003), I40-64 G.S. Goodwin-Gill and J. McAdam, The Refugee in International Law (2007), 345-54.

53 A. Grahl-Madsen, 'International Refugee Law Today and Tomorrow', (I982) Archiv des Völkerrechts, 439.

54 See Refugee Convention, supra note 47, Art. 33; I 957 Agreement Relating to Refugee Seamen, 506 UNTS I 25; I 975 Protocol to the Agreement Relating to Refugee Seamen, 965 UNTS445, Art. I 0; 1984 Convention against Torture, I 465 UNTS 85, Art. 3; 2006 International Convention for the Protection of All Persons from Enforced Disappearance, UN Doc. A/6I/488 (2006), Art. I6; see also I969 Convention Governing the Specific Aspects of Refugee Problems in Africa, Ioor UNTS 45, Art. II(3); ACHR, supra note 47, Art 22(8); I985 Inter-American Convention to Prevent and Punish Torture, OAS Treaty Series No. 67, Art. I3(4); ArCHR, supra note 47, Art. 28; Charter of Fundamental Rights of the European Union, supra note 44, Art. I9(2).

55 HRC, General Comment No. 20 Concerning Prohibition of Torture and Cruel Treatment or Punishment, UN Doc. HRI/GEN/I/Rev.9 (Vol. I) (I992), para. 9.

56 Committee on the Rights of the Child (CRC), General Comment No. 6: Treatment of Unaccompanied and Separated Children outside Their Country of Origin, UN Doc. CRC/GC/2005/6 (2005), para. 27.

57 Soering v. The United Kingdom, Decision of 7 July I989, [I989] ECHR (Ser. A.), at I6I, paras. 87-8. 
through the exclusion clauses of the refugee definition or in application of the exceptions contained in Article 33(2)..$^{58}$

\subsection{The contextual element of crimes against humanity}

While forced removal of non-citizens may fall within the definition of deportation under Article 7(2)(d) of the Rome Statute, it amounts to a crime against humanity if, and only if, such a deportation has been; committed as part of a widespread or systematic attack directed against any civilian population, with knowledge of the attack'. This contextual element captures the essence of crimes against humanity, which criminalizes only the most serious human rights violations because of their large-scale or massive nature.

The attack directed against any civilian population is defined by Article 7(2)(a) of the Rome Statute as 'a course of conduct involving the multiple commission of acts referred to in paragraph I against any civilian population, pursuant to or in furtherance of a state or organisational policy to commit such attack'. This definition combined with the above mentioned chapeau requires four cumulative conditions concerning respectively the attack; its widespread or systematic nature; the targeted group; the underlying state or organizational policy. Despite this relatively high threshold, it will be shown that, in some circumstances, deportation can fall within the ambit of the contextual element of crimes against humanity.

\subsection{The attack}

Although the term 'attack' is not defined in the Rome Statute, the Elements of Crimes clarifies that it does not need to be 'a military attack'. ${ }^{59}$ This is the natural consequence of the absence of a nexus with an armed conflict. While confirming this understanding, the ICC has construed the term 'attack' as referring to:

a campaign or operation carried out against the civilian population, the appropriate terminology used in article 7(2)(a) of the Statute being a "course of conduct". The commission of the acts referred to in article 7(I) of the Statute constitutes the "attack" itself and, beside the commission of the acts, no additional requirement for the existence of an "attack" should be proven. ${ }^{60}$

In other words, the same act may constitute both the underlying offence and the attack for the purpose of establishing a crime against humanity.

Following this reasoning, deportations amount to an attack without any further requirement. One single act of deportation is however not sufficient in itself to be considered as an attack. Article 7(2)(a) of the Rome Statute requires 'a course of conduct involving the multiple commission of acts referred to in paragraph I'. This accordingly refers to two situations: the attack is composed of several acts of deportation, or it is based on one single act of deportation provided, in such a case,

58 Chahal v. United Kingdom, Decision of I 5 November I996, [1997] 23 EHRR 4I3; CAT, Paez v. Sweden, UN Doc. CAT/C/I8/D/39/I996, (I996), para. I4.5.

59 Elements of Crimes, supra note 30, para. 3.

6o Prosecutor v. Bemba Gombo, Decision Pursuant to Article 6I(7)(a) and (b) of the Rome Statute on the Charges, PTC II, Case No. ICC-or/05-01/08-424, P.T.Ch. II, I 5 June 2009, para. 75. 
that one of the other underlying offences has been committed (such as murder, torture, persecution, imprisonment, apartheid, or 'other inhumane acts of a similar character intentionally causing great suffering, or serious injury to body or to mental or physical health').

These underlying offenses may indeed be committed in the course of the deportation process. For instance, excessive use of force in enforcing a deportation order can amount in some circumstances to murder, torture, or inhuman treatment. Furthermore, arbitrary or indefinite detention of migrants is by definition a 'severe deprivation of physical liberty in violation of fundamental rules of international law' under Article 7(I)(e) of the Rome Statute. In some other extreme cases, deportations may be part of a broader criminal design that amounts to persecution or apartheid. By contrast to most of the other underlying offences, persecution and apartheid do not necessarily involve physical violence - they may be perpetrated as a result of legislation or a government policy. ${ }^{6 \mathrm{I}}$ Besides these two exceptional cases, in practice an attack will be easily presumed from the acts of deportation themselves provided they fall within the definition of deportation and forcible transfer under Article $7(2)(d)$ of the Rome Statute. ${ }^{62}$

\subsubsection{The widespread or systematic nature of the attack}

While the attack is inherent to the acts of deportation, such an attack must still be 'widespread' or 'systematic'. Though these terms are not defined by the Rome Statute and the Elements of Crimes, the two conditions are clearly disjunctive such that 'the alleged act must be eitherwidespread orsystematic to warrant classification as crimes against humanity'. ${ }^{63}$ Alongside the ad hoc tribunals, the ICC further clarified that 'only the attack, and not the alleged individual acts are required to be "widespread" or "systematic"'. ${ }^{4}$ Thus, the relevant acts of deportation do not necessarily need to be widespread or systematic provided that they are part of a broader attack which meets this alternative requirement. This may happen when deportations are carried out as an integral component of a broader criminal design. Besides this eventuality, the acts of deportation must be carried out in a widespread or systematic manner. This alternative condition not only constitutes the main defining feature of the crime against humanity, but it is also the more demanding requirement compared to its other constitutive elements. Nevertheless, as explained below, the acts of deportation and the underlying context can still give rise to a widespread or systematic attack.

6 I W. Schabas, supra note 43, at I 53; A. Bultz, 'Redefining Apartheid in International Criminal Law', (2013) 24(2) Criminal Law Forum 226, at 227.

62 As mentioned above, if one of the conditions (such as a lawful presence) is lacking, deportation can still fall within the residual category of 'other inhumane acts' when it causes 'great suffering, or serious injury to body or to mental or physical health'.

63 Situation in the Republic of Kenya, Decision Pursuant to Article I 5 of the Rome Statute on the Authorization of an Investigation into the Situation in the Republic of Kenya, Case No. ICC-or/o9-I9-Corr, P.T.Ch. II, 3 I March 20Io, para. 94.

64 Ibid., para. 94; see also Prosecutor v. Kordic and Cerkez, Judgement, Case No. IT-95-I4/2-A, A.Ch., I7 December 2004, para 94; Prosecutor v. Deronjic, Judgement on Sentencing Appeal, Case No. IT-02-6I-A, A.Ch., 20 June 2005, para. I09; Kunarac et al., supra note 33, para. 96. 
The term 'widespread' has been construed by the Pre-Trial Chamber II as encompassing 'the large scale nature of the attack, which should be massive, frequent, carried out collectively with considerable seriousness and directed against a multiplicity of victims. ${ }^{65}$ It thus refers to 'both the large-scale nature of the attack and the number of resultant victims' ${ }^{66}$ Needless to say, this requirement is confined to some exceptional circumstances when collective expulsions have been perpetrated against a high number of non-citizens. Besides the number of victims, the widespread nature of the attack may also be inferred from the 'cumulative effect of a series of inhumane acts or the singular effect of an inhumane act of extraordinary magnitude'. ${ }^{67}$ The cumulative effect of the attack may be relevant when deportations are carried out in the wake of other underlying offences, such as arbitrary detention, torture or other inhumane acts under Article 7(I) of the Rome Statute.

Such a course of conduct may also fall within the ambit of the other alternative requirement. In contrast to the large-scale character of a 'widespread' attack, its 'systematic' nature is arguably more apt to be applied in the case of deportations. This alternative requirement has been consistently understood by the ICC as referring to:

either an organised plan in furtherance of a common policy, which follows a regular pattern and results in a continuous commission of acts or as patterns of crimes such that the crimes constitute a non-accidental repetition of similar criminal conduct on a regular basis. ${ }^{68}$

While such an organized plan or patterns of crimes are clearly contingent on the factual circumstances of each case, both entail that deportations follow a regular scheme. The requirement of an 'organized plan' would be most likely established when the crime of apartheid or persecution are associated with a common policy of deportations. In other cases, 'patterns of crimes' may still be found when deportations have been carried out alongside a repetition of other punishable acts (including indefinite or arbitrary detention, murder, torture, inhuman acts and other related mistreatments). In sum, though the term 'widespread' establishes a relatively high threshold (mainly confined to collective expulsion of a large number of individuals), the systematic nature of the attack may also be inferred from repeated acts of deportation associated with other underlying offences. In practice however the two alternative requirements may overlap.

65 Bemba, supra note 6o, para. 83; Prosecutor v. Katanga and Chui, Decision on the Confirmation of Charges, Case No. ICC-01/04-01/07-7 I7, P.T. Ch. I, 30 September 2008, para. 395.

66 Situation in the Republic of Kenya, supra note 63, para. 95; see also Prosecutor v. Gbagbo, Decision on the Confirmation of Charges against Laurent Gbagbo, Case No. ICC-02/I I-OI/I I, P.T.Ch. I, I2 June 20I4, para. 222; Bemba supra note 6o, para. 83; Prosecutor v. Harun and Kushayb, Decision on the Prosecution Application under Article 58(7) of the Statute, Case No. ICC-02/05-0I/07, P.T.Ch. I, 27 April 2007, para 62.

67 Situation in the Republic of Kenya, supra note 63, para. 95, referring to Blagojević and Jokić, supra note 33, para. 545; see also Bemba, supra note 60, para. 83.

68 Katanga and Chui, supra note 65, paras. 397-398; see also Situation in the Republic of Kenya, supra note 63, para. 96; Situation in the Republic of Côte d'Ivoire, Corrigendum to 'Decision Pursuant to Article I 5 of the Rome Statute on the Authorisation of an Investigation into the Situation in the Republic of Côte d'Ivoire', PTC III, Case No. ICC-02/I I-I 4-Corr, P.T.Ch. III, 23 June 20I I, para. 54; Gbagbo, supra note 66, para. 22. 


\subsubsection{The civilian population}

While the acts of deportation may in some circumstances equate with a widespread or systematic attack, the Rome Statute further requires such an attack to be 'directed against any civilian population'. This condition does not raise particular difficulties when applied to the deportation of non-citizens. As clarified by the ICTY, it does not require that the whole population of a state or a territory must be the object of the attack. ${ }^{69}$ The term 'population' refers instead to the collective nature of the crime (which must thus be perpetrated against more than one victim), whereas the expression 'directed against' underlines that the civilian population must be 'the primary object of the attack'. ${ }^{70}$

As a result, deportations of non-citizens can be considered as an 'attack directed against any civilian population' under the definition of the crime against humanity. This has been further confirmed by the ICC in several occasions. Its Pre-Trial Chamber II held that the civilian population refers to any 'groups distinguishable by nationality, ethnicity or other distinguishing features'. ${ }^{7 \mathrm{I}}$ It thus encompasses any non-citizens who are distinguishable by their nationalities provided of course that they are non-combatants.

\subsubsection{The policy requirement}

The last condition required by Article 7(2)(a) of the Rome Statute is also easily fulfilled when it comes to deportation of non-citizens. Such acts must be committed 'pursuant to or in furtherance of a State or organisational policy'. According to the Elements of Crimes, this presupposes that 'the State or organisation actively promote or encourage such an attack against a civilian population. ${ }^{72}$ Though the terms 'policy' and 'State or organisational' are not defined by the Rome Statute and the Elements of Crimes, the Pre-Trial Chamber II of the ICC clarified that:

The requirement of "a State or organizational policy" implies that the attack follows a regular pattern. Such a policy may be made by groups of person who govern a specific territory or by any organization with the capability to commit a widespread or systematic attack against a civilian population. The policy need not be formalised. Indeed, an attack which is planned, directed or organized - as opposed to spontaneous or isolated acts of violence - will satisfy this criterion. ${ }^{73}$

This requirement would be met when deportations are carried out by the organs of a state following a regular pattern. The Chamber further acknowledged that:

while ... the term "State" is self-explanatory, it is worth mentioning that in the case of a State policy to commit an attack, this policy "does not necessarily need to have

69 Kunarac et al., supra note 33, para. 90.

70 Ibid.; Prosecutor v. Mrkšić and Šljivančanin, Judgement, Case No. IT-95-I3/l-A, A.Ch., I 2 November 2009, paras. $30-4$.

7 I Prosecutor v. Ruto, Kosgey, and Sang, Decision on the Confirmation of Charges Pursuant to Article 6I(7)(a) and (b) of the Rome Statute, Case No. ICC-oI/o9-oI/I I, P.T.Ch. II, 23 January 20I 2, para. I64; see also Situation in the Republic of Kenya, supra note 63, para. 8I; Bemba, supra note 6o, para. 76; Katanga and Chui, supra note 65, para. 399.

72 See paragraph 3 of the introduction to crimes against humanity in Elements of Crimes, supra note 30.

73 Bemba, supra note 6o, para. 8I; see also Katanga and Chui, supra note 65, para. 396; Prosecutor v. Tadić, Opinion and Judgement, Case No. IT-94-I-T, 7 May I997, para. 653. 
been conceived at the highest level of the State machinery". Hence, a policy adopted by regional or even local organs of the State could satisfy the requirement of a State policy. ${ }^{74}$

Furthermore, the term 'organizational policy' includes non-state actors when 'organizations not linked to a State may, for the purposes of the Statute, elaborate and carry out a policy to commit an attack against a civilian population'. ${ }^{75}$

In sum, as demonstrated above, forced removal of non-citizens carried out in violation of international law may fall within the definition of deportation under the Rome Statute. Among the contextual elements of the crime against humanity, the notions of attack and of civilian population as well as the policy requirement can also be applied in the migration context without raising major difficulties. Deportations still have to be widespread or systematic. Accordingly, deportations must be of a large-scale character or at least follow a regular scheme whether as an organized plan or as patterns of crimes. Depending on the circumstances of the case, the systematic nature of the crime can be established from repeated acts of deportation associated with other underlying offences, such as arbitrary detentions of migrants or inhuman treatments.

\section{Deportation as a CRime of Genocide}

In contrast to crimes against humanity, genocide is much less relevant for criminalizing deportation. Though the two crimes overlap in substance and may be committed in times of war as well as of peace, the cautious definition of the I948 Convention on the Prevention and Punishment of the Crime of Genocide restated by Article 6 of the Rome Statute is confined to particularly exceptional circumstances. Indeed 'the crime of the crime ${ }^{76}$ must be committed with the "intent to destroy, in whole or in part, a national, ethnical, racial or religious group, as such'. More importantly deportation is not explicitly mentioned in the exhaustive list of genocidal acts: (i) Such omission needs further scrutiny especially when it comes to the practice of ethnic cleansing; (ii) deportation may nevertheless still play a role for substantiating a genocidal intent; and (iii) it may fall within the scope of the other genocidal acts.

\section{I. Deportation and genocide: the missed opportunity}

Contrary to war crimes and crimes against humanity, deportation is not explicitly mentioned in the definition of genocide. This silence of the Genocide Convention is the result of a failed attempt. During its drafting an amendment was proposed by Syria in order to add the act of 'imposing measures intended to oblige members of a group to abandon their homes in order to escape the threat of subsequent ill-treatment'. ${ }^{77}$ This amendment was rejected by 29 votes to 5 , with 8 abstentions. ${ }^{78}$

\footnotetext{
74 Situation in the Republic of Kenya, supra note 63, para. 89.

75 Ibid., para. 92.

76 Prosecutor v. Kambanda, Judgement and Sentence, Case No. ICTR-97-23-S, 4 September I998, para. I6; Krstić, supra note 33, para. 699.

77 Syria: Amendment to Article II, UN Doc. A/C.6/234 (I948) A/C.6/SR.8I, 22 October I 948.

78 UN Doc. A/C6/SR.82, I492 (I948).
} 
Although this rejection has been frequently overemphasized as excluding deportation from the crime of genocide, the travaux préparatoires give a much less categorical picture. States were clearly not ready in I 948 to accept the broad and ambiguous amendment submitted by Syria. Its proposal was indeed not limited to the act of deportation itself but included, more generally, any other indirect measures compelling persons to leave their home because of the threat of future mistreatments. Most delegates considered that this amendment 'went too far'79 or 'deviated too much from the original concept of genocide'. ${ }^{80}$ Referring to the Second World War, Yugoslavia argued on the contrary that:

the Nazis had dispersed a Slav majority from a certain part of Yugoslavia in order to establish a German majority there. That action was tantamount to the deliberate destruction of a group. Genocide could be committed by forcing members of a group to abandon their homes. ${ }^{81}$

The United States representative, however, objected that ' $[\mathrm{t}]$ he wording of the Syrian amendment was too indefinite to allow of strict interpretation: for example, the time factor came into play in the term "subsequent ill treatment". ${ }^{2}$ The Belgian delegate concurred that 'it should be made clear in the text that the threat of ill-treatment had to be serious in order to constitute genocide; if not, the concept of genocide would be given indefinite scope'. ${ }^{83}$

Against this background, the refusal of the Syrian amendment was more justified by the vagueness of its inclusive language than by any other speculative considerations. Since then, however, it has become conventional wisdom among scholars and tribunals to infer from the drafting history of the Genocide Convention a formal antinomy between the destruction of a group and its deportation. ${ }^{84}$ According to the ICTY:

[i]t does not suffice to deport a group or a part of a group. A clear distinction must be drawn between physical destruction and mere dissolution of a group. The expulsion of a group or part of a group does not in itself suffice for genocide. ${ }^{85}$

One should nevertheless observe that the distinction between destruction and deportation has been primarily aimed at distinguishing genocide from ethnic cleansing. This last term has raised longstanding controversies since it was used for the first time at the international level in 1992 in the context of the war in the former Yugoslavia. ${ }^{86}$ Most of the difficulties raised by this notion stem from the fact that it is

79 Ibid., at I490 (India).

80 Ibid., (USA); Ibid., at I49I (UK and Cuba); Ibid., at I 492 (Egypt and Iran).

8 I Ibid., at I490.

82 Ibid., at $\mathrm{I} 494$.

83 Ibid., at I490.

84 See most notably W. Schabas, Genocide in International Law. The Crime of Crimes (2009), 233-4; L. van der Herik, 'The Meaning of the Word 'Destroy' and its Implication for the Wider Understanding of the Concept of Genocide', in H.G. van der Wilt et al. (eds.) The Genocide Convention. The Legacy of 60 Years (20I 2), 5 I-8.

85 Prosecutor v. Stakić, Judgement, Case No. IT-97-24-T, T. Ch. II, 3I July 2003, para. 5I9; see also Report of the International Commission of Inquiry on Darfur to the United Nations Secretary General (2005), I3 I-2.

86 UN Security Council, Security Council Resolution 77 I (I992) on the Former Yugoslavia, UN Doc. S/RES/77 I (I992), I3 August I992, para. 2; UN General Assembly, General Assembly Resolution 47/I2 I (I992) on the Situation in Bosnia and Herzegovina, UN Doc. A/RES/47/I 2 I (I992), I 8 December I992. On the longstanding 
not an international crime on its own. Instead, it is a factual term increasingly used for describing the practice of 'rendering an area ethnically homogenous by using force or intimidation to remove persons of given groups from the area' ${ }^{87}$

While forced removal constitutes its main defining feature (and thus overlaps with war crimes and crimes against humanity), this attribute has been heralded as the dividing line between ethnic cleansing and genocide. Endorsing the view of the ICTY, the ICJ underscored that:

Neither the intent, as a matter of policy, to render an area "ethnically homogeneous", nor the operations that may be carried out to implement such policy, can as such be designated as genocide: the intent that characterizes genocide is "to destroy, in whole or in part" a particular group, and deportation or displacement of the members of a group, even if effected by force, is not necessarily equivalent to destruction of that group, nor is such destruction an automatic consequence of the displacement. ${ }^{88}$

Although the Court overemphasized the differences between the two, it had to concede that in some circumstances ethnic cleansing may still satisfy specific requirements of the crime of genocide. ${ }^{89}$ This conclusion was reached by the ICC in clearer and more convincing terms in the Al Bashir case. While referring to the ICJ and ICTY judgments mentioned above, the Court concluded that:

this does not mean that the practice of ethnic cleansing - which usually amounts to the crime against humanity of persecution - can never result in the commission of the crime of genocide. .... [S] uch a practice may result in genocide if it brings about the commission of the objective elements of genocide provided for in article 6 of the Statute and the Elements of Crimes with the dolus specialis/specific intent to destroy in whole or in part the targeted group..$^{90}$

The ICC thus acknowledged that the formal distinction between genocide and ethnic cleansing is porous and does not fairly reflect the complexity of their interactions. In fact, although deportation does not equate with destruction, it may still substantiate the genocidal intent and even fall within the ambit of the genocidal acts.

debates about this notion, see D. Petrovic, 'Ethnic Cleansing - An Attempt at Methodology', (I 994) 5(I) EJIL 342-59; R.M. Hayden, 'Schindler's Fate: Genocide, Ethnic Cleansing, and Population Transfers', 55(4) Slavic Review 727-48 (I996); L.D. Manashaw, 'Genocide and Ethnic Cleansing: Why the Distinction? A Discussion in the Context of Atrocities Occurring in Sudan', (2005) 35 CWILJ 303, 329; W. Schabas, "Ethnic Cleansing” and Genocide: Similarities and Distinctions', (2003-2004) 3 European Yearbook of Minority Issues, Io9-28; C. Pégorier, Ethnic Cleansing: A Legal qualification, (2013).

87 Interim Report by the Commission of Experts, S/35374 (I993), para. 55. This definition has been endorsed by both the ICJ and the ICC. Application of the Convention on the Prevention and Punishment of the Crime of Genocide (Bosnia and Herzegovina v. Serbia and Montenegro), Judgment of 26 February 2007, [2007] ICJ Rep. 43, para. 90; Prosecutor v. Al Bashir, Decision on the Prosecution's Application for a Warrant of Arrest against Omar Hassan Ahmad Al Bashir, Case No. ICC-02/05-0i/o9, P.T.Ch. I., 4 March 2009, para. I43.

88 Application of the Genocide Convention, supra note 87, para.I90.

89 "This is not to say that acts described as "ethnic cleansing" may never constitute genocide, if they are such as to be characterized as ... contrary to Article II ... of the Convention, provided such action is carried out with the necessary specific intent (dolus specialis), that is to say with a view to the destruction of the group, as distinct from its removal from the region.' Ibid. 


\subsection{Deportation and genocidal intent}

Clearly, the 'intent to destroy, in whole or in part, a national, ethnical, racial or religious group, as such' constitutes the quintessence of the crime of genocide. As restated by the ICTY and ICTR, "[t]he victims of the crime must be targeted because of their membership in the protected group, although not necessarily solely because of such memberships'. ${ }^{\text {I }}$ Indeed, some other motives may still coexist with genocidal intent..$^{2}$ For instance, even if the alleged purpose is to enforce immigration laws by deporting members of the relevant group, this does not obviate the existence of a genocidal intent. In some circumstances, such an allegedly lawful purpose can even be used as an excuse or an instrument for carrying out a genocide. This eventuality requires two clarifications regarding the targeted group and the threshold required by the genocidal intent.

One should first of all acknowledge that non-citizens do not constitute a protected group as such. Both the ICJ and the ICC require instead a positive determination of the group: 'the targeted group must have particular positive characteristics (national, ethnic, racial or religious), and not a lack thereof ... It is, therefore, a matter of who the targeted people are, not who they are not'. ${ }^{93}$ Thus, similarly to the category of the 'non-Serb' population, 'non-citizens' do not constitute a protected group on their own. In practice however, most of them would fall within the groups enumerated in the definition of genocide, most notably when they are targeted as a national group. This group is conventionally understood as 'a collection of people who are perceived to share a legal bond based on common citizenship, coupled with reciprocity of rights and duties'. ${ }^{94}$ Alternatively, non-citizens can fall under an ethnic group as 'a group whose members share a common language or culture'95 or a racial one 'based on the hereditary physical traits often identified with a geographical region, irrespective of linguistic, cultural, national or religious factors'.$^{96}$

Secondly, even if non-citizens may be targeted as a national, ethnic, racial or religious group, the intention to destroy such a group requires a systematic pattern, ${ }^{97}$ thereby excluding 'isolated acts of racially motivated violence'. ${ }^{98}$ Nevertheless the intention to destroy a protected group can be confined to a limited geographic zone, provided that a substantial part of the group is targeted. ${ }^{99}$ More significantly, one should highlight that, even for the tribunals which formally distinguish the intention to destroy from the intention to deport, they all concede that the latter

9I Blagojević and Jokić, supra note 33, para. 669; Prosecutor v. Ntakirutimana and Ntakirutimana, Judgement, Cases Nos. ICTR-96-Io-A and ICTR-96-I7-A, I3 December 2004, para. 363.

92 Prosecutor v. Niyitegeka, Judgement, Case No. ICTR-96-I4-A, 9 July 2004, paras. 5 I-3.

93 Al Bashir, supra note 87, para. I35; Application of the Genocide Convention, supra note 87, paras. I93, I 97.

94 Prosecutor v. Akayesu Judgement, Case No. ICTR-96-4-T, 2 September I 998, para. 5I 2, endorsing the well-known definition of nationality given by the ICJ in the Nottebohm case.

95 Ibid., at para. $5 \mathrm{I} 3$.

96 Ibid., at paras. 5I4, 5I5. The same observation applies a fortiori to a religious group 'whose members share the same religion, denomination or mode of worship'.

97 Prosecutor v. Jelisić, Judgement, Case No. IT-95-Io-A, A.Ch., 5 July, 200I, para. 47; see also Akayesu, supra note 94, para. 523; Elements of Crimes, supra note 30.

98 Schabas, supra note 43, at I 27; see also S. Glaser, Droit international pénal conventionnel (1970), ro9.

99 Application of the Genocide Convention, supra note 87, paras. I98-9; Al Bashir, supra note 87, para. I46; Prosecutor v. Krstić, Judgement, Case No. IT-98-33-A, A.Ch., 30 March 2004, paras. 8-I I. 
may be indicative of the former. In other words, deportation and forcible transfer may be used to infer the genocidal intent even if they do not equate with it. As restated by the ICJ, 'acts of "ethnic cleansing” .... may be significant as indicative of the presence of a specific intent (dolus specialis) inspiring those acts. ${ }^{\text {'0o }}$ This highlights in turn the intimate connection between genocide and ethnic cleansing as an integral part of the same criminal design.

The ICTY Appeals Chamber (AC) equally concurred in the Krstić case: '[t]he fact that the forcible transfer does not constitute in and of itself a genocidal act does not preclude ... from relying on it as evidence of the intentions of members of the VRS Main Staff' to destroy the group. ${ }^{\text {IOI }}$ The role of deportation and forcible transfer for substantiating a genocidal intent has also been confirmed by domestic courts. In particular, the Federal Constitutional Court of Germany held in the Jorgic case that 'systematic expulsion can be a method of destruction and therefore an indication though not the sole substantiation, of an intention to destroy. ${ }^{\text {'02 }}$ The Federal Constitutional Court even went one step further by interpreting the term 'destroy' in a broader sense so as to encompass the social existence of a group. ${ }^{\text {I03 }}$ It is true that this broad interpretation is at odds with the literal one of the ICJ and the ICTY which is circumscribed to biological and physical destruction only. The European Court of Human Rights (ECtHR) has however confirmed the ruling of the German Court:

[T] he domestic courts' interpretation of 'intent to destroy a group' as not necessitating a physical destruction of the group, which has also been adopted by a number of scholars $\ldots$, is ... covered by the wording, read in its context, of the crime of genocide in the Criminal Code and does not appear unreasonable ... Therefore, the national courts' interpretation of the crime of genocide could reasonably be regarded as consistent with the essence of that offence and could reasonably be foreseen by the applicant at the material time. ${ }^{\text {I04 }}$

Indeed, the genocidal acts listed in Article II of the I948 Convention and Article 6 of the Rome Statute are not confined to the physical destruction of a group as they also include forcible transfers of children. This presupposes that the destruction of a protected group may be reached by other means than purely physical and biological ones. Furthermore, the national, ethnic, racial or religious groups are by definition social entities and protected as such for 'the victim of the crime of genocide is the group itself and not only the individual'. ${ }^{\text {I05 }}$ Destroying the group as a social unit may have the same result as killing its individual members. Such an interpretation is supported by the effet utile of the prohibition of genocide as well as the object and purpose of the I948 Convention, which must be construed as a living instrument and not as a relic of the past.

\footnotetext{
Ioo Application of the Genocide Convention, supra note 87, para. I90.

IOI Krstić, supra note 99, para. 33.

I02 Federal Constitutional Court, I 2 December 2000, 2 BvR I 290/99, para. 25 (Ger.).

I03 Ibid., at para. 20.

I04 Jorgic v. Germany, App. No. 746I3/or, Decision of I 2 July 2007, [2007] ECHR, at paras. I05, I I4.

I05 Akayesu, supra note 94, para. 52 I.
} 
As notably acknowledged by Judge Shahabudden, "[i]t is not apparent why an intent to destroy a group in a non-physical or non-biological way should be outside the ordinary reach of the Convention'. ${ }^{\text {I06 }}$ The ICTY TC further concurred in the Krajisnik case that:

"Destruction", as a component of the mens rea of genocide, is not limited to physical or biological destruction of the group's members, since the group (or a part of it) can be destroyed in other ways, such as by transferring children out of the group (or the part) or by severing the bonds among its members. ${ }^{107}$

Although this view was not confirmed by the majority of the AC, there is a growing trend in favour of a broader interpretation of the term 'destruction' under the definition of the crime of genocide. It has not only been endorsed by judges and scholars ${ }^{\text {I08 }}$ but also by the UN General Assembly for which 'the abhorrent policy of "ethnic cleansing" ... is a form of genocide.' ${ }^{\text {I09 }}$ The ECtHR further clarified that, at the domestic level, states can prosecute the destruction of a protected group as a social entity without frustrating the text and the purpose of the crime of genocide. At the international level, however, it is still premature to consider these developments as reflecting customary international law. The conventional wisdom acknowledged by the ICJ and the ICTY remains confined to the physical and biological destruction of a group. ${ }^{\text {II }}$ But even from this narrow perspective, deportation and forcible transfer rarely stand alone in practice. They are frequently imbricated with other acts of physical or biological destruction to such an extent that forced displacement may equally exhibit the genocidal intent.

I06 Krstić, supra note 99, para, 49. He further explains: 'It is the group which is protected. A group is constituted by characteristics - often intangible - binding together a collection of people as a social unit. If those characteristics have been destroyed in pursuance of the intent with which a listed act of a physical or biological nature was done, it is not convincing to say that the destruction, though effectively obliterating the group, is not genocide because the obliteration was not physical or biological.' Ibid., at para. 50.

I07 Prosecutor v. Krajisnik, Judgement, Case No. IT-oo-39-T, T. Ch. I, 2006, 27 September 2006, para. 854; see also Prosecutor v. Brđanin, Judgement, Case No. IT-99-36-T, T. Ch. II, I September 2004, para. 98I: 'there are obvious similarities between a genocidal policy and the policy commonly known as ethnic cleansing. The underlying criminal acts for each may often be the same'.

I08 Al Bashir, supra note 87, paras. 57-62 (Judge A. Usacka, Separate and Partly Dissenting Opinion); Application of the Convention on the Prevention and Punishment of the Crime of Genocide (Bosnia and Herzegovina v. Yugoslavia (Serbia and Montenegro)), Request for the Indication of Provisional Measures, Order of 8 April I993, [I993] ICJ Rep. 3, para.69 (Judge Lauterpacht, Separate Opinion); M. Sirkin, 'Expanding the Crime of Genocide to Include Ethnic Cleansing: A Return to Established Principles in Light of Contemporary Interpretations', (2010) 33(2) SULR, 489-526; L. May, Genocide. A Normative Account (2010), I05-8; G. Werle, 'German Jurisprudence on Genocidal Intent and the European Convention for the Protection of Human Rights and Fundamental Freedoms', in K. Nuotio (ed.) Festschrift in honour of Raimo Lahti (2008), 50-7; O. Triffterer and C. Rosbaud, H. Hinterhofer, StGB - Salzburger Kommentar zum Strafgesetzbuch\$32 I mn. (2005), 69; A. Cassese, International Criminal Law (2008), I35; M. Lippman, 'Genocide: The Crime of the Century', (200I) 23 HJIL 526; J. Hübner, Das Verbrechen des Völkermordes im Internationalen und Nationalen Recht (2004), 208-17.

Io9 UNGA Resolution 47/I2I (I992), supranote 86; see also UN Sub-Commission on Prevention of Discrimination and Protection of Minorities, Report of the Sub-Commission on Prevention of Discrimination and Protections of Minorities on its 45th Session, Resolution I993/8 on Punishment of the Crime of Genocide, 25 October I993, UN Doc. E/CN.4/I 994/2-E/CN.4/sub.2/I993/45; Final Report of the Commission of Experts Established Pursuant to Security Council Resolution 780 (I992), UN Doc. S/I994/674 (I994), Part. III(B), para. I 29.

I Io Since the writing of this article, the ICJ has confirmed its rather conservative position in its judgment of 3 February 2015: Application of the Convention on the Prevention and Punishment of the Crime of Genocide (Croatia $v$. Serbia), Judgment of 3 February 2015 (not yet published). 


\subsection{Deportation and genocidal acts}

Though deportation is not explicitly mentioned in Article II of the Genocide Convention and Article 6 of the Rome Statute, it may fall within the ambit of three genocidal acts out of the five enumerated therein. The most obvious one includes forcibly transferring children of the group to another group. The notion of transfer is broad enough to cover any forced displacement within and outside the territory. Otherwise, excluding deportation from its scope would make this provision meaningless, and would defeat its very purpose.

The Elements of Crimes further provides a broad definition of the term 'forcibly': it can be physical (as apparent from an act of deportation), or psychological (including threat of coercion, duress, detention or abuse of power for leaving the country). Thus, as restated by the ICTR, '[t]he objective is not only to sanction a direct act of forcible physical transfer, but also to sanction acts of threats or trauma which would lead to the forcible transfer of children from one group to another'. ${ }^{\text {II }}$ However, this underlying offence suffers from a substantial qualification regarding the destination of such forcible removal: it only prohibits transfer from one group to another. Therefore, relocation of children within the same group is outside the scope of this provision. Nevertheless, such a relocation can still amount to one of the other underlying offences enumerated in the Genocide Convention and the Rome Statute.

The second relevant genocidal act consists in 'deliberately inflicting on the group conditions of life calculated to bring about its physical destruction in whole or in part'. This provision has been construed as covering 'circumstances which will lead to a slow death' without requiring the actual destruction of the group nor the killing of its members. ${ }^{\text {II }}$ The fact that deportation can be used as a measure of 'slow death' has been acknowledged by both the ICJ ${ }^{\mathrm{II} 3}$ and the International Law Commission. ${ }^{\text {II } 4}$ This interpretation is further confirmed by the Elements of Crimes as well as the jurisprudence of the ICTR and ICTY. ${ }^{\text {II }}$ Against such a frame, one should be not surprised to see that in the Al Bashir case, the ICC Pre-Trial Chamber I came to the following conclusion:

[T] he acts of contamination of water-pumps and forcible transfer coupled by resettlement by member of other tribes, were committed in furtherance of the genocidal policy, and that the conditions of life inflicted on the Fur, Masalit and Zaghawa groups were calculated to bring about the physical destruction of a part of those ethnic groups. ${ }^{\text {II }}$

The last and most relevant genocidal act concerns those 'causing serious bodily or mental harm to members of the group'. The wording of this provision is broad enough to include deportation and forcible transfer when they are carried out in such a way as to cause serious harms. Already in I961, the Eichmann Judgment

\footnotetext{
I I A Aayesu, supra note 94, para. 509.

I 2 Prosecutor v. Kayishema and Ruzindana, Judgement, Case No. ICTR-95-I-T, T.Ch. II, 2 I May I999, paras.I I5-I6; Brđanin, supra note I07, para. 69I.

II3 Application of the Genocide Convention, supra note 87, para.I90.

I 4 ILC, Report of the International Law Commission on the Work of its Forty-Eighth Session, UN Doc. A/5I/Io (I996), at 9I.

I 5 Akayesu, supra note 94, paras. 505-6; Brđanin, supra note I07, para. 69I.

I 6 Prosecutor v. Al Bashir, Second Decision on the Prosecution's Application for a Warrant of Arrest, Case No. ICC-02/05-01/09, P.T.Ch. I, I 2 July 2010, para. 38.
} 
included deportation among the acts that could constitute serious bodily or mental harm. ${ }^{\text {II7 }}$ This interpretation has been confirmed by the ICTY. ${ }^{\text {II } 8}$ While referring to the case-law of the ICTR, the Trial Chamber (TC) in Krstić concluded that inhuman treatment ... and deportation are among the acts which may cause serious bodily or mental injury'. ${ }^{\text {II } 9}$

The TC further restated that whether an act of deportation causes such serious harm 'must be assessed on a case-by-case basis and with due regard for the particular circumstances' of the case. ${ }^{\text {I20 }}$ The relevant circumstances presumably include the use of force and other related mistreatments in carrying out deportation, as well as the age, gender, and health of the deportees. The ICC has also arrived at the same conclusion, even though the Elements of Crimes does not explicitly refer to deportation and forcible transfer in their non-exhaustive list of serious harms. The ICC Pre-Trial Chamber I held in the Al Bashir case that forcible displacement falls under the material element of the crime of genocide by causing serious bodily or mental harm. ${ }^{\text {I2I }}$

\section{Conclusion: Migration and international Criminal JUSTICE: THE WAY FORWARD}

Although deportation is traditionally considered as an attribute of the state inherent to its territorial sovereignty, this prerogative may degenerate into an international crime. This article clarifies that in some circumstances, deportation can amount to a war crime, a crime against humanity or even a crime of genocide. Though neglected by scholars and practitioners, international criminal law has an important role to play for sanctioning the most patent abuses against migrants. The scope and content of each particular crime are however, complex, and substantially vary from one to another depending on their constitutive elements and the surrounding circumstances of each case. Their transposition into the context of migration control must accordingly be done with caution and with due regard to their respective requirements.

Among the various crimes reviewed in this article, genocide is bound to be circumscribed to truly exceptional cases because of the high threshold required by its dolus specialis. For the time being, it is thus mainly confined to the situation in Sudan. As explained above, the 'crime of crimes' still needs to be revisited in order to better take into account deportation and ethnic cleansing as an instrument of oppression aimed at destroying a national, racial, ethnic or religious groups.

In times of armed conflict and occupation, the prohibition of unlawful deportation and forcible transfer constitutes a well-established principle of IHL which

I 7 The Israeli Government Prosecutor General v. Eichmann, Jerusalem District Court (I96I), 36 ILR 340 (I 968).

I 8 See for example Prosecutor v. Karadžić and Mladić, Review of the Indictments Pursuant to Rule 6I of the Rules of Procedure and Evidence, Case No. IT-95-5-R6I and IT-95-I8-R6I, T.Ch., I I July I996, para. 93.

I 9 Krstić, supra note 30, para. 513.

I 20 Ibid.

I2 I Al Bashir, supra note I 6, para. 30. 
is part of customary international law. ${ }^{\mathrm{I22}}$ Despite the limit inherent to the nexus with an armed conflict, this prohibition is applicable to a substantial range of 23 states, including those with an important number of undocumented migrants and asylum-seekers, such as Colombia, Lebanon, Mexico, Morocco, Thailand and Turkey.

Crimes against humanity are potentially applicable to a broader number of states especially since it can be committed in times of peace. As demonstrated in this article, deportations carried out alongside other underlying offences (such as arbitrary detention or inhuman treatment) may amount to a widespread or systematic attack under the definition of crimes against humanity. Allegations of forcible displacement in the Democratic Republic of Congo, Kenya, and Sudan are currently being examined by the ICC. These cases would be instrumental in clarifying the scope of crimes against humanity in relation to deportation and forcible transfer; but similar allegations could still be raised in other regions of the world.

Among the most obvious instances, there are reasonable grounds for asserting that a crime against humanity could have been committed in the Dominican Republic with regard to its deportation policy of Haitian migrants. UN treaty bodies have regularly expressed their concerns about 'recurring reports of mass, indiscriminate and arbitrary deportations' against Haitians. ${ }^{\text {I23 }}$ Deportations are not only acknowledged as a blatant breach of international law, but they are also carried out in a context of widespread abuses such as arbitrary detention, discriminatory treatment and violence against Haitian migrants and their descendants, ${ }^{\mathrm{I} 24}$ abusive withdrawals of citizenship and confiscations of identity documents, ${ }^{\mathrm{I} 25}$ racial discrimination, ${ }^{\mathrm{I} 26}$ as well as other instances of exploitation, forced labour, and cruel, inhuman, and degrading treatment. ${ }^{\mathrm{I} 27}$

The findings of UN treaty bodies have been further corroborated by the InterAmerican Court of Human Rights, which has held on several occasions that deportations and other related mistreatments have violated a broad range of fundamental rights (including the rights to juridical personality, human treatment, personal

I 22 J.-M. Henckaerts and L. Doswald-Beck, Customary International Humanitarian Law Vol. I, (2005), 457, Rule I 29.

I23 HRC, Concluding Observations: Dominican Republic, UN Doc. CCPR/CO/7 I/DOM (200I), para. I6; see also Committee on the Elimination of Racial Discrimination (CERD), Concluding Observations: Dominican Republic, UN Doc. CERD/C/DOM/CO/I3-I4 (20I3), para. 2I; CERD, Concluding Observations: Dominican Republic, UN Doc. CERD/C/DOM/CO/I2 (2008), para. I3.

I24 HRC, Concluding Observations: Dominican Republic, UN Doc. CCPR/C/DOM/CO/5 (2OI 2), paras. 7 and 20.

I25 CERD, Concluding Observations (2013), supra note I23, paras. I9-20; CERD, Concluding Observations (2008), supra note I23, para. 2 I; Committee on the Elimination of Discrimination against Women (CEDAW), Concluding Observations: Dominican Republic, UN Doc. CEDAW/C/DOM/CO/6-7 (2013) para. 30; HRC, Concluding Observations (20I2), supra note I24, paras. 22-3.

I26 CERD, Concluding Observations (20I3), supra note I23, paras. 9, I I; CERD, Concluding Observations (2008), supra note I 23, para. 2 I; Committee on Economic, Social and Cultural Rights (CESCR), Concluding Observations: Dominican Republic, UN Doc. E/C.I 2/DOM/CO/3 (20I0), paras. I I, I 8; CRC, Concluding Observations: Dominican Republic, UN Doc. CRC/C/DOM/CO/2 (2008), para. 28; CRC, Concluding Observations: Dominican Republic, UN Doc. CRC/C/I5/Add.I50 (200I), paras. 22, 26; UN Human Rights Council, Report of the Special Rapporteur on Contemporary Forms of Racism, Racial Discrimination, Xenophobia and Related intolerance, Doudou Diène, and the Independent Expert on Minority Issues, Gay McDougall, Mission to Dominican Republic, UN Doc. A/HRC/7/23/Add.3 (2008), I 8 March 2008, paras. 36-50 and I02-9.

I 27 See CERD, Concluding Observations (2013), supra note I23, para. I4; CERD, Concluding Observations (2008), supra note I23, para.I8; CESCR, Concluding Observations: Dominican Republic, UN Doc. E/C.I2/I/Add.6 (I996), paras. I3-I5; HRC, Concluding Observations: Dominican Republic, UN Doc. CCPR/C/79/Add.I8 (I993), paras. 5, 9. 
liberty, fair trial, protection of the family, rights of the child, nationality, property, freedom of movement and residence, equality and non-discrimination, and juridical protection). ${ }^{\mathrm{I} 28}$ It is true that state responsibility must not be confused with the criminal responsibility of individuals, and that not every breach of human rights law constitutes an international crime. However, the numerous and converging evidence reported above exhibit a reasonable basis to believe that the removal policy of Haitian migrants corresponds to the definition of deportation under the Rome Statute and has been committed in a widespread or systematic manner in line with the requirements of the crime against humanity as interpreted above in this article.

To a lesser extent, there have been allegations of crimes against humanity committed in Australia in relation to its deportation policy and mandatory detention of asylum-seekers. The policy of intercepting boat people clearly violates the principle of non-refoulement when asylum-seekers are directly sent back to their countries of origin, as happened to 4I Sri Lankan nationals in July 20I4. ${ }^{\text {I29 }}$ In any event, the removal of asylum-seekers toward third states such as Manus Islands and Nauru, is still contrary to international law because of torture, degrading treatment, and sexual violence regularly reported therein. ${ }^{\mathrm{I} 30}$ Furthermore, a large range of treaty bodies ${ }^{\mathrm{I} 3 \mathrm{I}}$ and the UN High Commissioner for Refugees ${ }^{132}$ have acknowledged on numerous occasions that the Australian policy of systematically detaining asylum-seekers violates international human rights law and refugee law, because it is carried out on a mandatory and indefinite basis without any individualized assessment nor effective

I 28 Tide Méndez et al. v. Dominican Republic, Decision of 29 March 2012 Merits, IACtHR, Case No. I 2.27I, Rep. No. 64/I2 (2012); The Girls Yean and Bosico, Yean and Cofi v. Dominican Republic, Interpretation of the Judgment of Preliminary Objections, Merits, Reparations and Costs, 23 November 2006, [2006] IACHR (Ser. C), at I56; The Yean and Bosico Children v. Dominican Republic, Judgment of Preliminary Objections, Merits, Reparations and Costs, 8 September 2005, [2005] IACHR (Ser. C), at I 30.

I 29 O. Laughland and S.K. Dehghan, 'Australia Accused of Breaking Law After Returning AsylumSeekers to Sri-Lanka', The Guardian (2014), available at www.theguardian.com/world/2014/jul/ o7/australia-accused-breaking-law-returning-asylum-seekers-sri-lanka.

I30 Among many other acknowledgements see Kaldor Centre for International Refugee Law, 'Inquiry into the Incident at the Manus Island Detention Centre from I6 to I 8 February', Submission 9, 2 May 20I4; Amnesty International, 'This Is Breaking People: Human Rights Violations at Australia's Asylum Seeker Processing Centre on Manus Island, Papua New Guinea', (20I3); Amnesty International, 'This Is Still Breaking People: Update on Human Rights Violations at Australia's Asylum Seeker Processing Centre on Manus Island, Papua New Guinea', (20I4); UNHCR, 'UNHCR Monitoring Visit to the Republic of Nauru - 7 to 9 October 20I3', 26 November 2013.

I3 I As far as the HRC is concerned, see among many other instances: HRC, M.M.M. et al. v. Australia, 28 October 20I3, UN Doc. CCPR/C/I08/D/2I36/20I 2 (20I3); F.K.A.G. et al. v. Australia, 28 October 20I3, UN Doc. CCPR/C/ro8/D/2094/20I I (2013); Fong v. Australia, 23 November 2009, UN Doc. CCPR/C/97/D/I442/2005 (2009); Shams et al. v. Australia, 20 July 2007, UN Doc. CCPR/C/9o/D/I 255, I 256, I 259, I 260, I 266, I 268, I 270 , I 288/2004 (2007); D. and E. v. Australia, 9 August 2006, UN Doc. CCPR/C/87/D/1050/2002 (2006); Madafferi v. Australia, 26 August 2004, UN Doc. CCPR/C/8I/D/Ior I/200I (2004); C. v. Australia, 28 October 2002, UN Doc. CCPR/C/76/D/90o/I999 (2002); A. v. Australia, 3 April I997, UN Doc. CCPR/C/59/D/560/1993 (I997); see also CAT, Concluding Observations: Australia, UN Doc. CAT/C/AUS/CO/3 (2008), paras. I I-I7; CERD, Concluding Observations: Australia, UN Doc. CERD/C/AUS/CO/I5-I7 (2010), para. 23; CERD, Concluding Observations: Australia, UN Doc. CERD/C/AUS/CO/I4 (2005), para. 23; CRC, Concluding Observations: Australia, UN Doc. CRC/C/AUS/CO/4 (20I2), paras. 3I-2, 58, 8I, CRC, Concluding Observations: Australia, UN Doc. CRC/C/I5/Add.268 (2005), paras. 62-4; Report of the Working Group on Arbitrary Detention: Visit to Australia, UN Doc. E/CN.4/2003/8/Add.2 (2002).

I32 See UNHCR, 'UNHCR Monitoring Visit to Manus Island, Papua New Guinea: 23 to 25 October 20I3', 26 November 2013. 
judicial review. ${ }^{\mathrm{I} 33}$ Against such a background, there are some reasonable grounds to argue that the systematic nature of these unlawful deportations associated with the state policy of arbitrary detention may reach the threshold required to be considered a crime against humanity under the conditions detailed in the present article. ${ }^{34}$

As exemplified by the Dominican Republic and Australia, international criminal law opens new perspectives for sanctioning widespread or systematic abuses against migrants. Although both states have ratified the Rome Statute, bringing such cases before the ICC is obviously not an easy task in light of its limited resources and the broad discretion of its Prosecutor to open an investigation. Beyond the usual requirements governing the geographic and temporal jurisdiction of the ICC, the main criterion relied on by the Prosecutor to open an investigation is the gravity of the case. ${ }^{135}$ Although the gravity test has been applied so far in a restrictive way, there is no reason to exclude proprio motu the most serious abuses against migrants when there is a reasonable basis to believe that a crime within the jurisdiction of the ICC has been perpetrated. Moreover, such an investigation would be instrumental in discarding the longstanding critique that the ICC only focuses on African states to the detriment of similar situations in other states.

Whatever the potential role of the ICC is for prosecuting large-scale abuses against migrants, the most likely and robust way to enforce international criminal law relies on domestic courts. Criminal prosecutions can be initiated by domestic tribunals either in the states of origin of abused migrants or, when applicable, in any other states in accordance with the principle of universal jurisdiction. This is notably acknowledged by the Rome Statute which recalls 'the duty of every State to exercise its criminal jurisdiction over those responsible for international crimes. ${ }^{136}$ The main virtue of international criminal law is not only repressive but also more importantly preventive. From this angle, a better understanding of forcible displacement as a crime of international law constitutes a prerequisite for infusing the rule of law into the field of migration.

Domesticating the state's prerogative of deportation remains a critical step in order to ensure due respect for the human rights of migrants. This is further consonant with the broader evolution of public international law, which is gradually moving from a state-centred to an individual-oriented paradigm. As acknowledged the ICTY in the Tadić case:

It would be a travesty of law and a betrayal of the universal need for justice, should the concept of State sovereignty be allowed to be raised successfully against human rights. Borders should not be considered as a shield against the reach of the law and as a protection for those who trample underfoot the most elementary rights of humanity. ${ }^{\mathrm{I}}{ }^{37}$

I33 For an overview see especially B. Saul, 'Dark Justice: Australia's Indefinite Detention of Refugees on Security Grounds under International Human Rights Law', (2OI2) I3(2) MJIL I-47.

I34 See also the following study published after the writing of this article: C. Henderson, 'Australia's Treatment of Asylum-Seekers. From Human Rights Violations to Crimes against Humanity', (20I4) I2 JICJ I I6I-8I.

I 35 ICC, Office of the Prosecutor, 'Policy Paper on Preliminary Examinations', (2013) 3 at I 5-I6.

I36 Rome Statute, supra note 7, Preamble, para. 6.

I37 Tadić, supra note I2, para. 58. 